\title{
Prevalence of Chagas disease in blood donors at the Uberaba Regional Blood Center, Brazil, from 1995 to 2009
}

\author{
Laryssa Manso de Limaa ${ }^{[1]}$, Nathália Passos Alves ${ }^{[2]}$, Valdirene de Fátima Barbosa ${ }^{[3]}$, \\ Gustavo Alves Pimenta ${ }^{[4]}$, Helio Moraes-Souza ${ }^{[5]}$ and Paulo Roberto Juliano Martins ${ }^{[5]}$
}

[1]. Curso de Medicina, Universidade Federal do Triângulo Mineiro, Uberaba, MG. [2]. Curso de Medicina, Universidade de Uberaba, Uberaba, MG. [3]. Grupo de Pesquisa de Segurança Transfusional - CNPq-UFTM, Uberaba, MG. [4]. Disciplina de Bioestatística, Universidade Federal do Triângulo Mineiro, Uberaba, MG. [5]. Disciplina de Hematologia e Hemoterapia, Universidade Federal do Triângulo Mineiro, Uberaba, MG.

\begin{abstract}
Introduction: A retrospective study was conducted to assess the occurrence of blood donations that were ineligible due to Chagas disease infection? from 1995 to 2009 at the Uberaba Regional Blood Center (HRU), Brazil, verify the tendency of this ineligibility, and describe the epidemiologic profile of the donors. Methods: Retrospective studies of serological ineligibility due to Chagas disease, statistical analysis by means of the chi-square test and odds ratio, study of the tendencies using a dispersion graph and the linear correlation coefficient $(r)$ were performed. Results: In the period under study, a $0.2 \%$ serum prevalence of ineligibility due to Chagas disease was found, with a significant drop in ineligible donations from 2001 to 2009. Among the serum positive-donors, there was a significant predominance among those aged 30 years or above and non-single individuals. Conclusions: The results show a rate of occurrence that is lower than that described in literature, as well as a progressive drop during the 15 years under assessment. Such results are a consequence of systematic combat of the vector since the $70 \mathrm{~s}$ and the progressive and consistent increase of returning donors, resulting in a drop of the contamination risk factor by means of blood transfusion and in the improvement of the quality of hemotherapy practices in the HRU.
\end{abstract}

Keywords: Chagas disease. Transmission by transfusion. Blood donors. Serologic ineligibility.

\section{INTRODUCTION}

Chagas disease is a parasitic disease caused by infection with the flagellated protozoan Trypanosoma cruzi, which has triatominae insects as vectors ${ }^{1,2}$. This disease affects approximately 8 million people in Latin America, with around 108 million people living in high-risk areas. In Brazil, with 2.5 million infected people, the disease is a particularly important health problem due to its high morbidity and mortality rate ${ }^{3}$.

The major forms of transmission of Chagas disease are by vectors, transfusion, and congenital; the latter has recently shown great epidemiological importance ${ }^{4}$. World Health Organization (WHO) initiatives and those commissioned by Latin American governments have led to the control of the vectoral transmission of the disease in various endemic areas by the main vector, Triatoma infestans, by means of preventive measures to avoid home triatomism².

With step-by-step control of natural transmission, particularly by means of eradication of the vector in various endemic countries, blood transfusions became the main mechanism of dissemination of Chagas disease in these countries during the $80 \mathrm{~s}$ and the $90 \mathrm{~s}^{5}$. The possibility of transmission of this disease by means of blood transfusion was rumored in 1936 in Argentina ${ }^{6}$ and confirmed in 1952 in Brazil ${ }^{7}$.

The reduction of the prevalence of Chagas disease among blood donors, a consequence of the eradication of the main vector ( $T$. infestans) and of the high serological coverage, resulting from

Address to: Dr. Paulo Roberto Juliano Martins. Disc. de Hematologia e Hemoterapia/UFTM. Av. Getúlio Guaritá 250/4ㅇandar, Bairro Abadia, 38025-440 Uberaba, MG, Brasil.

Phone: 5534 3312-5077

e-mail: paulo.martins@hemominas.mg.gov.br

Received in 14/10/2011

Accepted in 13/01/2012 internalization and better qualification of the public hemo-web and a more effective performance of sanitary vigilance over the public and private hemotherapy services, has contributed to the increased safety of blood transfusions in Brazil ${ }^{8}$.

The risk of a patient being infected while receiving a unit of blood from a donor with Chagas disease is variable. It may reach $49 \%$ in regions with high rates of vector transmissions such as Santa Cruz, Bolivia, while the risk may be approximately $12 \%-18 \%$ in countries with low rates of natural transmission such as Argentina, Brazil, Chile, and Uruguay. In non-endemic countries the risk is even lower ${ }^{9-11}$.

According to Moraes-Souza, while the serological prevalence of Chagas disease in blood donors in Latin America and Brazil in the 70s, was $6.49 \%$ and $6.96 \%$ respectively, in 2006 it decreased to $1.28 \%$ and $0.21 \%$. In Uberaba, the reduction in serum prevalence in this period was from $16.02 \%$ to $0.14 \%^{3,12,13}$.

The reasons for such a significant decrease in Chagas disease infections in donors in the region of Uberaba, coinciding with urbanization of peasants originating from highly endemic areas at least 4 decades ago, deserves a more accurate investigation. The specific purposes of this study were to calculate the rate of occurrence of ineligibility due to Chagas disease at the Uberaba Regional Blood Center (HRU), Brazil, from 1995 to 2009, to verify the tendency of this ineligibility during this period, and to describe the profile of the Chagas disease-infected donors according to gender, age, marital status, race, and origin.

\section{METHODS}

This was a retrospective and descriptive study of data obtained from the files of the Hemominas Foundation regarding all blood donations with serologic ineligibility due to Chagas disease positivity measured by means of enzyme-linked immunosorbent assay (ELISA) 
and indirect immunofluorescence (IFI) up to July 13, 2004 (MS: Ministry of Health, Ordinance number 1376) ${ }^{14}$ and ELISA after July 14, 2004 (RDC/ANVISA number 153: Resolução da Diretoria Colegiada/Agência Nacional de Vigilância Sanitária) ${ }^{15}$, from January 1, 1995 to December 31, 2009 at the HRU. The donors' personal data were preserved, and they were identified by registration number to ensure confidentiality.

The occurrence of ineligible donations due to Chagas disease infection was calculated, and a statistical, descriptive analysis was carried out from absolute and relative frequencies. To verify the tendency of this ineligibility during the study period, a graph was drawn illustrating dispersion and the linear correlation coefficient $(r)$, with a significance level of $5 \%$.

For the epidemiological characterization, the following parameters were taken into consideration: gender (male and female), age group (18-29 years and 30 years or above), marital status (single, married, other) race (white and non-white), and origin (from Uberaba and not from Uberaba). To study the associations between the characteristics of interest, the chi-square test and odds ratio calculations were performed ${ }^{16}$.

\section{Ethical considerations}

This study was carried out after approval was granted by the Committee for Ethics in Research of the Hemominas Foundation (no. 264).

\section{RESULTS}

During the period under study (1995-2009), the HRU registered 295,850 candidates for blood donations and of those, $60,916(20.6 \%)$ were discarded at the clinical selection stage. Out of the 234,934 blood donations, 218,989 were liberated for transfusion (serologically eligible) and 15,945 (6.8\%) were serologically ineligible. Out of the ineligible donations, 541 (0.2\%) were serologically ineligible due to Chagas disease positivity by means of ELISA and IFI (Table 1).

The occurrence rate of ineligible blood donations due to Chagas disease positivity was higher during the years of 1996-1998 and 2000, with a peak of $0.4 \%$ and a subsequent slow decrease, with the smallest value recorded in 2008 at $0.05 \%$ (Table 2).
TABLE 1 - Rate of clinical and serological ineligibility (total and for Chagas disease) of the 295,850 candidates for blood donations at the HRU, Brazil, from 1995 to 2009.

\begin{tabular}{lrc}
\hline Parameters & Number & Percentage \\
\hline Candidates for blood donation & 295,850 & 100.0 \\
Clinically ineligible & 60,916 & 20.6 \\
Clinically eligible & 234,934 & 79.4 \\
Serologically eligible & 218,989 & 93.2 \\
Serologically ineligible & 15,945 & 6.8 \\
Ineligible due to Chagas disease & 541 & 0.2
\end{tabular}

Source: Data bank at the Hemominas Foundation - Uberaba Regional Blood Center (HRU).

TABLE 2 - Annual occurrence of ineligible blood donations for positive or undetermined serology for Chagas disease, at the HRU, Brazil, from 1995 to 2009.

\begin{tabular}{lrcc}
\hline & \multicolumn{3}{c}{ Annual blood donations } \\
\cline { 2 - 4 } Year & Total & Ineligible (n) & Ineligible (\%) \\
\hline 1995 & 9,948 & 41 & 0.4 \\
1996 & 13,121 & 59 & 0.4 \\
1997 & 17,427 & 62 & 0.4 \\
1998 & 18,782 & 66 & 0.4 \\
1999 & 16,253 & 47 & 0.3 \\
2000 & 16,444 & 57 & 0.4 \\
2001 & 15,319 & 50 & 0.3 \\
2002 & 15,514 & 20 & 0.1 \\
2003 & 15,950 & 25 & 0.2 \\
2004 & 15,828 & 28 & 0.2 \\
2005 & 16,073 & 24 & 0.2 \\
2006 & 16,426 & 14 & 0.09 \\
2007 & 15,764 & 27 & 0.2 \\
2008 & 16,025 & 8 & 0.05 \\
2009 & 16,060 & 13 & 0.08 \\
\hline Total & $\mathbf{2 3 4 , 9 3 4}$ & $\mathbf{5 4 1}$ & $\mathbf{0 . 2}$
\end{tabular}

Source: Data bank at the Hemominas Foundation/Uberaba Regional Blood Center (HRU).

There was a significant decrease in the occurrence of ineligibility for positive or undetermined serology for Chagas; while analyzing the tendencies of these blood donations by regression, we verified that this percentage decreased by 0.03 each year (Figure 1).

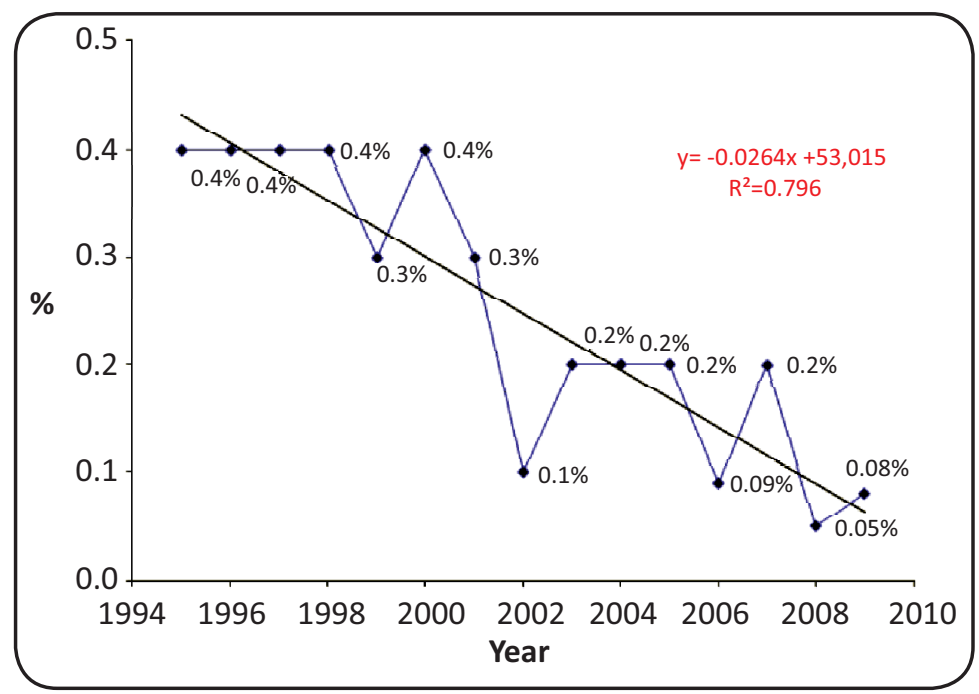

FIGURE 1 - Percentages of ineligible donations due to positive or undetermined serology for Chagas disease at the HRU, Brazil, from 1995 to 2009. ( $\left.y=-0.0264 x+53,015 ; R^{2}=0.796\right)$. HRU: Uberaba Regional Blood Center. 
Between 1995 and 2008, the HRU received 528 blood donations with ineligibility due to Chagas positivity in 522 distinct donors. The epidemiological profile of these ineligible donors and their correlation with the 60,811 blood donors during the study period is shown in Table 3. We verified a statistically significant predominance of donors aged 30 years or above $(p<0.0001)$ and those that were married or were in other stable relationships $(p<0.0001)$ when compared to single individuals (Table 3 ).

\section{DISCUSSION}

During the period under study, the occurrence rate for ineligible blood donations due to Chagas disease positivity was $0.2 \%$ (by ELISA and IFI), and during the years 1996-1998 and 2000 this rate was $0.4 \%$ (highest rate), with an abrupt fall from 2002 onwards, reaching $0.05 \%$ in the year 2008 . A study involving national public and private services in 2004 reported a prevalence of $0.6 \%{ }^{17}$, while a WHO document from 2006 revealed prevalence rates for Chagas disease-infected donors for all of Latin America of $1.28 \%$ and for Brazil of $0.21 \%{ }^{3}$. Other studies reported a prevalence of serum positivity for Chagas disease of $0.4 \%$ at the São Lucas Hospital at

Pontificate Catholic University (PUC) in Rio Grande do Sul, Brazil, from 2005-2006 $6^{18}, 0.41 \%$ in the Independence Hospital in Porto Alegre from 2006 to $2008^{19}$, and $0.17 \%$ in the Pernambuco Regional Blood Center from January 2002 to December $2007^{20}$. In Uberaba, the prevalence rate decreased from $16 \%$ in the 70 s to $0.14 \%$ in $2006^{12}$. This latter study and the current study show that, despite the fact that Uberaba has already been a highly endemic area for Chagas disease, today it has one of the lowest national prevalence rates among blood donors.

The variation of incidence rates among various studies may be due to the differences in methodologies used, variation in the socioeconomic and epidemiologic conditions of the population of each region, the use of various serological techniques, and the size of the samples in each study.

The strong decreasing tendency for ineligibility due to Chagas disease infection ( $r=-0.89$ ) during the 15 years of this study is likely due to factors such as systematic combat of the vector in the region since the 70s and the exhaustive work in the promoting customer loyalty of the blood donors at the HRU, which began more than 3 decades ago; today, more than $80 \%$ of blood donations are from return donors, the majority of which are fidelity donors ${ }^{12}$. Concerning the epidemiologic profile of those who were ineligible in relation to the total number of donors, the proportion of ineligible donors aged 30 years and above was significantly higher (which is in agreement with the literature, and expected given the vector-eliminating initiatives implemented in the endemic regions of the country $)^{12}$; individuals that were married and in other stable relationships also had increased ineligibility rates relative to single donors. The highest occurrence in married people and those in other stable relationships may be explained by their correlation with the higher age group in comparison to the single individuals. As a consequence of eradication of the triatomines in our region some years ago, a smaller number of Chagas disease-infected individuals in the younger age group are entering the list of donors and there has been a progressive decrease of infected donors, whether by age or morbidity or mortality due to the illness ${ }^{18}$.

This type of study suffers from the contention effect in the system that represses pre-seropositive candidates facing new donations. To reduce this effect, the blood centers summon donors to collect second samples and to repeat serologic tests. If they are negative in this sample, they return to the normal flow of donations. For donors that are truly positive, there is no way to eliminate this contention effect since the Health Ministry and ANVISA require exclusion of these donors due to the high risk of transmission of Chagas disease via blood transfusion. Donors seropositive for T. cruzi are permanently excluded from blood donation and sent to the cardiology ambulatory of Hospital Clinics of the Federal University of the UFTM, for diagnostic confirmation, orientation, and treatment.

This study showed the progressive decrease of the occurrence of serologic ineligibility due to Chagas disease positivity of donors at the Uberaba HRU during the 15 years analyzed. These findings confirm the importance of a systematic combat initiative to the relevant vector and the customer fidelity of the donors in the reduction of the transmission of the illness via blood transfusion, and consequently, in the increase in the safety of transfusions.

Due to limitations on the available database in which we have summaries of frequencies calculated in a bivariate form, the analysis of the bivariate association used here limits our knowledge about which of the isolated factors and/or combinations of these factors could better explain the ineligibility of the donation by $T$. cruzi. Therefore, as the results obtained are limited to isolated bivariate associations, the inference of this study is limited to this sphere. 


\section{ACKNOWLEDGMENTS}

We thank the staff at the Uberaba Regional Blood Center (HRU) and the Hemominas Foundation for their contribution to the development of this study.

\section{CONFLICT OF INTEREST}

The authors declare that there is no conflict of interest.

\section{FINANCIAL SUPPORT}

Laryssa Manso de Lima is a scholarship holder of the Scientific Initiation Foundation scholarship to support research in the State of Minas Gerais (FAPEMIG).

\section{ABSTRACT IN PORTUGUESE}

\section{Prevalência da doença de Chagas em doadores de sangue do Hemocentro Regional de Uberaba, Brasil, entre 1995 e 2009}

Introdução: Estudo retrospectivo com o objetivo de avaliar a ocorrência de doações inaptas para doença de Chagas entre 1995 e 2009 no Hemocentro Regional de Uberaba (HRU), Brasil; verificar a tendência dessa inaptidão e descrever o perfil epidemiológico dos doadores. Métodos: Estudo retrospectivo da inaptidão sorológica para doença de Chagas; análise estatística pelo teste do qui quadrado e odds ratio; estudo de tendência a partir do gráfico de dispersão e do coeficiente de correlação linear ( $r$ ). Resultados: No período em estudo foi encontrada uma soroprevalência de inaptidão para doença de Chagas de $0.2 \%$ com queda significativa de doações inaptas de 2001 a 2009. Dentre os soropositivos, observou-se predomínio significante na idade superior ou igual a 30 anos, e estado civil casado e outros. Conclusões: Os resultados demonstram taxa de ocorrência menor que as descritas na literatura, além de queda progressiva no decorrer dos 15 anos avaliados. Tais resultados são consequência do combate sistemático ao vetor a partir dos anos 70 e do progressivo e consistente aumento de doadores de retorno, resultando em queda do risco de contaminação via transfusão de sangue e na melhora da qualidade da hemoterapia praticada no HRU.

Palavras-chaves: Doença de Chagas. Transmissão transfusional. Doadores de sangue. Inaptidão sorológica.

\section{REFERENCES}

1. Silveira AC. Controle da doença de Chagas - diretrizes técnicas. $2^{\text {nd }}$ ed. Belo Horizonte: Secretaria de Estado de Minas Gerais; 2001.

2. Fundação Oswaldo Cruz (FIOCRUZ). Doença de Chagas - Web Site. [Internet]. Rio de Janeiro: (FIOCRUZ); [Cited 2011 September 02]. Available from: http://www.fiocruz.br/chagas/cgi/cgilua.exe/sys/start.htm?tpl=home/.
3. Organização Panamericana de Saude Publica (OPAS). Estimación Cuantitativa de la Enfermedad de Chagas en las Américas; 2006. 28 p. [Cited 2011 July 10]. Available from: http://www.bvsops.org.uy/pdf/chagas19.pdf.

4. Lana M, Tafuri WL. Trypanosoma cruzi e Doença de Chagas. In: Neves DP, Melo AL, Linardi PM, Vitor RWA, editors. Parasitologia Humana. $11^{\text {th }}$ Ed. São Paulo: Editora Atheneu, 2005, p. 85-108.

5. Moraes-Souza H, Ferreira-Silva MM. O controle da transmissão transfusional. Rev Soc Bras Med Trop 2011; 44:64-67.

6. Mazza S, Montana A, Benetez C, Janzi EZ. Transmisión del Schizothypanum cruzi al niño por leche de la madre con enfermedad de Chagas. Mepra 1936; 28:41-46.

7. Freitas JLP, Amato Neto V, Sonntag R, Biancalama A, Nussenzweig V, Barreto JG. Primeiras retificações de transmissão acidental da moléstia de Chagas ao homem por transfusão de sangue. Rev Paulista Medicina 1952; 40:36-40.

8. Moncayo A. Chagas Disease: Current Epidemiological Trends After the Interruption of Vectorial and Transfusional Transmission in the Southern Cone Countries. Mem Inst Oswaldo Cruz 2003; 98:577-591.

9. Schmunis GA. Trypanosoma cruzi. The etiologic agent of Chagas' disease: status in the blood supply in the endemic and non endemic countries. Transfusion 1991; 31:547-557.

10. Leiby DA, Fucci MH, Stumpf RJ. Trypanosoma cruzi in a low-to moderate-risk blood donor population. Transfusion 1999; 39: 310-315.

11. Blood Products Advisory Committee. Transcripts of the September 12, 2002, Blood Products Advisory Committee Meeting. Rockuble (MD): Food and Drug Administration/Center for Biologics Evaluation and Research (FDA/CBER); 2002.

12. Moraes-Souza H, Martins PRJ, Pereira GA, Ferreira-Silva MM, Abud MB. Perfil sorológico para doença de Chagas dos doadores de sangue do Hemocentro Regional de Uberaba. Rev Bras Hematol Hemoter 2006; 28:110-114.

13. Moraes-Souza H. Transmissão transfusional da doença de Chagas. Rev Patologia Tropical 2000; 29:91-100.

14. Agência Nacional de Vigilância Sanitária (ANVISA). Portaria N 1.376, de 19 de novembro de 1993. [Cited 2011 September 02]. Available from http://www.anvisa. gov.br/legis/portarias/1376-93.pdf/.

15. Agência Nacional de Vigilância Sanitária (ANVISA). Resolução RDC N 153, de 14 de junho de 2004. Publicada no Diário Oficial da união de 24 de junho de 2004. [Cited 2011 September 02]. Available from: http://portal.saude.gov.br/ portal/arquivos/pdf/resolucao_153_2004.pdf/.

16. Callegari-Jaques SM. Bioestatística - Princípios e Aplicações. $2^{\text {nd }}$. Porto Alegre: Editora Artmed; 2003.

17. Wendel S. Risco da transmissão da infecção por Trypanosoma cruzi por via transfusional no Brasil. [Thesis]. [São Paulo]: Faculdade de Medicina da USP; 2005. 404p.

18. Lunardelli A, Borges FP, Mello KF, Zeferino ASA. Soroprevalência da doença de Chagas em candidatos a doadores de sangue. Rev Bras An Clin 2007; 39:139-141.

19. Fitarelle DB, Horn JF. Descarte de bolsas de sangue devido à reatividade para doença de Chagas em um laboratório de triagem sorológica de doadores em Porto Alegre-RS. Rev Bras Hematol Hemoter 2009; 31:310-314.

20. Melo AS, Lorena VMB, Moraes AB, Pinto MBA, Leão SC, Soares AKA, et al. Prevalência de infecção chagásica em doadores de sangue no estado de Pernambuco, Brasil. Rev Bras Hematol Hemoter 2009; 31:69-73. 